\title{
Identification and Diagnostics of Plant-Symbiotic and Phytopathogenic Bacteria
}

\author{
Nataliya Vladimirovna Punina ${ }^{1}$, Mikhail Anatolievich Remnev ${ }^{2}$ and Alexey Fedorovich Topunov ${ }^{1}$ \\ 1. A. N. Bach Institute of Biochemistry RAS, Moscow 119071, Russia \\ 2. The Federal State Unitary Enterprise All-Russia Research Institute of Automatics, Moscow 127055, Russia
}

\begin{abstract}
Rapid and reliable diagnostics and identification of pathogenic and symbiotic bacteria are at the top of the agenda. In the first case, they are important to control and prevent crop damages, and thus reduce economic losses. In the second, it's necessary to design and monitor quality of biofertilizer to raise its effectiveness and crop capacity. Development of accurately, rapidly, technically and commercially accessible methods remains a critical problem for the bacteria with comprehensive phylogenetic structure. In this work, we investigated pathogenic Xanthomonas and Ralstonia and symbiotic Sinorhizobium. The aim of this investigation was to examine the applicability of the novel methods for phylogenetic study, identification and diagnostics of closely related species of these genera. The conventional phenotypic and genotypic (16S rRNA, gyrB) methods were applied as referents. Novel polymerase chain reaction (PCR)-based approaches, single-adapter amplified fragment length polymorphism (saAFLP) and comparative analyses of hin-region and Xcc0006-0007 sequences, were first employed for the investigations. Phenotypic tests, 16S rRNA and gyrB analysis distinguished bacteria at the genus level, but failed to identify them to the species robustly. The new methods identified bacteria at the inter-species level more precisely. This identification agreed with the accepted genera's classifications. The only exceptions were $X$. fuscans \& $X$. citri and $X$. perforance \& $X$. euvesicatoria which clustered together. The further outcome of this study was achieved hin-region-based genus-specific PCR primers for the express-diagnostics of the genera. Summary, these new methods can be applied for genome-based phylogeny investigations and as convenient and accurate tools for identification and routine laboratory diagnostics of these comprehensive genera.
\end{abstract}

Key words: Hin-region, saAFLP, Xanthomonas, Rhizobium, Sinorhizobium, Ralstonia.

\section{Introduction}

Plan-associated bacteria share a long history with plants and profound impact on the health and agricultural yield of crop [1]. There are two main groups of bacteria based on their adverse/beneficial effects on the host plants: pathogens and mutualists [2]. Investigation of the plant-bacterial interactions and microorganism's taxonomic classification are the most important and developing directions of the present biology [1]. The received knowledge can be used in agricultural and biotechnological sectors: (1) to diagnose most prevalent and most economically important pathogens and prevent plant diseases; (2) to identify and describe most common groups of

Corresponding author: Nataliya Vladimirovna Punina, Ph.D., research fields: microbiology and molecular biology. E-mail: hin-enkelte@yandex.ru. beneficial associates and symbiotic microbes for biofertilizer design; (3) to provide surveillance and control for both pathogenic and beneficial bacteria, and thus prevent a bacterial diseases and increase a crop yield.

For a long time, bacterial classification has been based largely on culture and biochemical tests, DNA-DNA hybridization, and 16S rRNA gene sequencing analysis [3]. Nowadays, classification, identification and diagnostics integrate also new techniques to determine both phenotypic and genotypic characteristics [3-7]. The use of multilocus sequence typing (MLST), multilocus sequence analysis (MLSA) and protein-typing are becoming very important for delineation of plant pathogenic and symbiotic bacteria at species level and lower level [8]. Over the last few years, these methods were improved 
dramatically: increasingly mechanized to raise speed, discrimination power and throughput, and to reduce cost of the laboratory analysis [9-16]. However, every method has its limitations and selection of the integrated approaches significantly depends on the target microorganism, time limits, assay accuracy and geographical scale [3, 17]. These methodical disadvantages has become more complicated due to globalization, climate change, increased human mobility and bacterial evolution. Therefore, there is a strong need to develop more rapid, accurate and universal techniques and methods to identify and detect economically important bacteria.

In this work, we studied two kinds of bacteria characterized by the type of nutrition and agricultural importance: phytopathogenic genera Xanthomonas and Ralstonia and symbiotic Sinorhizobium. Xanthomonas and Ralstonia affect more than 400 species of agricultural crops, causing bacteriosis and thus leading to major economic losses [18, 19]. Their taxonomic structures are intricate and are being constantly revised [20-22]. These genera had been subjected to numerous studies to clarify the taxonomy and phylogeny, although all applied methods were partially sufficient for their identification and diagnostics [21-27]. The disadvantage of the present diagnostics of these genera is testing of the strain at the one taxonomic level and only a certain known group of bacteria. Therefore, the development of new rapid and efficient methods is still crucial for detection and identification of these phytopathogens.

The genus Sinorhizobium (Ensifer) contains bacteria capable to fixate nitrogen in symbiosis with leguminous plants including agricultural crops, e.g., soybeans [28]. This genus contains closely-related species, and some of them are prospective for soybean biofertilizer production [29]. Identification and characterization of this genus are necessary to reveal and select most efficient symbiotic bacteria, create most productive plant-symbiont combination and thus increase crop capacity of fields. Different phenotypic and genetic methods were applied before [28]. There is still a need for rapid, accurate, easy and low-cost approaches that can be applied to production for identification (control and monitor) of the industrial strains.

In this work, the new DNA marker hin-region and single-adapter amplified fragment length polymorphism (saAFLP) analysis were first used to identify and describe the closely-related strains of the genera Xanthomonas, Ralstonia and Sinorhizobium. Obtained results were compared with data derived by the traditional pathogenicity and biochemical, comparative analysis of $16 \mathrm{~S}$ rRNA, gyrB and Xcc0006-0007 nucleotide sequences. The potential of new methods for identification and diagnostics of strains was evaluated for these genera.

\section{Materials and Methods}

\subsection{Bacterial Strains}

The original and type strains from weeds and agricultural crops were used in this study. One hundred and fourteen strains of Xanthomonas spp. were provided from All-Russian collection of microorganisms, G. K. Skryabin Institute of Biochemistry and Physiology of Microorganisms (VKM IBPM RAS; Pustchino, Russia), and Zabolotny Institute of Microbiology and Virology, National Academy of Sciences of Ukraine (IMV; Kiev, Ukraine). Twelve Ralstonia sp. strains were isolated from wilted tomato and potato in Russia. The known cultures of these genera obtained from the International Collection of Phytopathogenic Bacteria (ICPB; Davis, CA, USA), American Type Culture Collection (ATCC; Manassas, VA, USA) and National Collection of Plant-Pathogenic Bacteria (NCPPB; York, England) were also included for reference. Two referential strains of nitrogen-fixing Sinorhizobium meliloti B-117 and B-1009 were received from the collection of VKM IBPM RAS. Nine strains of Sinorhizobium spp. were isolated from root nodules of field-grown soybeans in Russia in 2013. 


\subsection{DNA Isolation}

The overall cellular DNA specimens were isolated from strains cultured on agarized yeast extract and tryptone (TY) medium $(\mathrm{g} / \mathrm{L}): 5.0 \mathrm{~g} / \mathrm{L}$ yeast extract, $10.0 \mathrm{~g} / \mathrm{L}$ bacto-tryptone, $10.0 \mathrm{~g} / \mathrm{L} \mathrm{NaCl}$ and $20.0 \mathrm{~g} / \mathrm{L}$ agar. DNA was isolated from cells on days 1-2 of culture by sorption onto magnetic particles ("Silex", Russia).

\subsection{Phenotypic Characterization}

The morphological and biochemical characteristics of the pure bacterial cultures were determined based on the general strategy of phenotypic differentiation described in Refs. [30-32].

\subsection{Pathogenicity Identification: Plant Nodulation Tests}

All strains of genera Xanthomonas and Ralstonia were tested for their pathogenicity on wide host range using previously described methodology [33]. Four-week-old seedlings (two- to three-leaf-stage) of tomato, cabbage, pepper, geranium and tobacco were inoculated by leaf and steam inoculation methods. The incubated plants were then kept on a greenhouse bench until symptoms development. Each experiment was repeated three times. Results were recorded $7 \mathrm{~d}$ and $16 \mathrm{~d}$ after inoculation.

\subsection{Polymerase Chain Reaction (PCR) Amplification and Sequencing of the 16S rRNA Gene}

The PCR analysis and subsequent determination of the 16S rRNA nucleotide sequences were conducted using the universal primers and protocols as described previously [34]. All amplified fragments were separated by an electrophoresis on $1.5 \%$ agarose gel. Sequencing was carried out using genetic analyzer 3130x1, "Applied Biosystems" (ABI) automated sequencing machine (USA).

2.6 PCR Amplification and Sequencing of the gyrB Gene

Nearly complete DNA sequences of the gyrB gene were amplified and sequenced using previously constructed primers UP1/UP2r and protocols [35].

\subsection{PCR Amplification and Sequencing of the Xcc0006-0007 Region}

Nucleotide sequences of the Xcc0006-0007 region of Xanthomonas spp. were amplified and sequenced according previously published protocol [36].

\section{8 saAFLP Analysis}

We modified amplified fragment length polymorphism (AFLP) method developed before by Vos et al. [37] and named new modification as saAFLP [38, 39]. The phylogenetic relationships between closely related strains Bacilllus cereus group and Rhizobium leguminosarum had been successfully analyzed using this method $[38,39]$. The procedure of saAFLP comprises three steps: (1) treatment of the extracted bacterial DNA by one of the genus specific restriction endonucleases and ligation with the single stranded adapter; (2) PCR amplification with the single primer which is complementary to the adapter sequence; (3) electrophoretic separation of the PCR products in agarose gel. The fundamentally new aspects of this methodological procedure include: (1) performing restriction analysis and ligase reaction in the same tube concurrently; (2) selecting restriction endonucleases by using computational analysis ("ReVer", Remnev and Punina, 2014, unpublished) so that we can obtain 10-30 DNA fragments after the treatment; (3) using the one single-stranded adapter.

\subsection{PCR Amplification and Sequencing of Hin-Region}

Hin-region amplification was carried out using primers designed specifically for the genera Sinorhizobium, Ralstonia and Xanthomonas. The primers and PCR amplification protocols were patented for the genera Rhizobium and Xanthomonas [40].

\subsection{Analysis of the Nucleotide Sequences}

The primary comparative analysis of the DNA 
sequences determined in this study and represented in the Gen Bank database was carried out using the National Center for Biotechnology Information's Basic Local Alignment Search Tool (NCBI BLAST) [41]. Sequence alignment was performed using the Clustal W 1.75 v software [42]. Based on nucleotide data, the phylogenetic trees were concatenated and constructed with the neighbor joining (NJ) [43] and minimum evolution (ME) [44] methods of MEGA 3.1 software [45].

\section{Results and Discussion}

\subsection{Genus Xanthomonas}

All bacterial cultures with different biochemical characteristics were tested on the corresponded test plants and produced either systemic or leaf spot lesions under glasshouse conditions. According to the 16S rRNA analysis, all strains were reliably (> 97\% similarity with type strain ATCC 33913T) identified as Xanthomonas spp.. After confirmation that investigated strains were affiliated to the same genus, DNA sequences of the gyrB gene [35] were sequenced (2,395 bp, $97.96 \%$ of whole its length) for all of them. Through cluster analysis (Fig. 1a), eight clades were branched with high bootstrap values $(>70 \%)$. Seven clades robustly comprised seven species $(X$. campestris, $X$. gardneri, $X$. translucence, $X$. oryzae, $X$. arboricola, $X$. vesicatoria and $X$. albilineans). Seven strains were poorly discriminated. They formed the one clade together with other $X$. euvesicatoria, $X$. perforance, $X$. citri, $X$. fuscans and $X$. axonopodis reference strains, and probably were just synonyms. These data were supported by recent genomic comparative analysis [26] and MLST analysis [21]. For example, it had been hypothesized that $X$. citri and $X$. fuscans could belong to a single species [26]. Comparison of the gyrB DNA sequences revealed high variability for intra- (similarity values were greater than $79.3 \%$ ) and inter-species (>97.5\%) levels for Xanthomonas spp..

Despite the fact that this analysis is considered as a convenient and accurate tool to discriminate the majority of established species in the genus Xanthomonas [46], four close-related species were not supported with high branching level.

As it was shown before, comparative analysis of the DNA sequences of the Xcc0006-0007 operon (length $1,971 \mathrm{bp}, 86.30 \%$ per whole length) is sufficient to

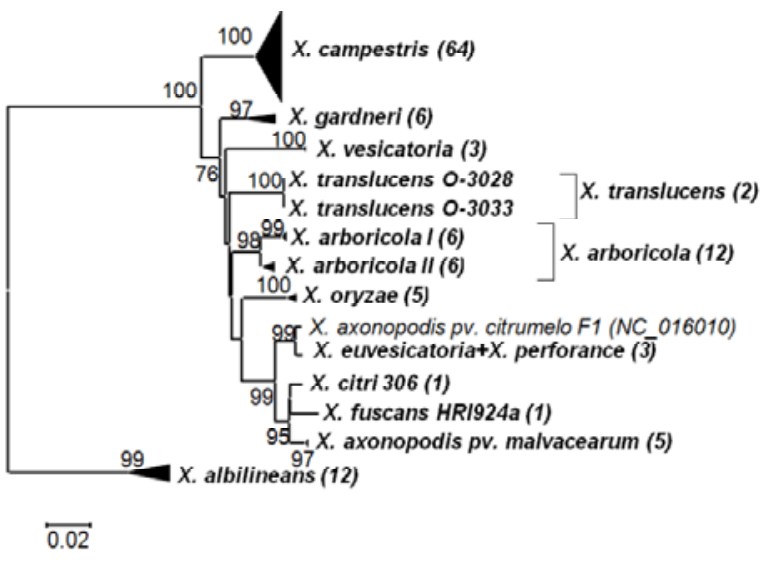

(a)

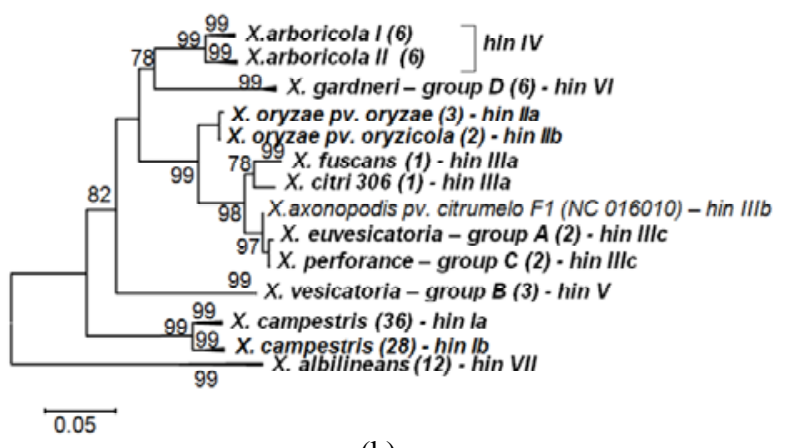

(b)

Fig. 1 NJ tree of the nucleotide sequences for the gyrB gene (a) and hin-region (b), based on 115 strains of Xanthomonas.

The scale corresponds to the number of substitutions per 100 base pairs (genetic distances). The numerals show statistical reliability of the branching order (\%) defined by bootstrap analysis (1,000 replicas). Bootstrap values less $70 \%$ are not shown. The numbers in parentheses shows the amount of the investigated strains.

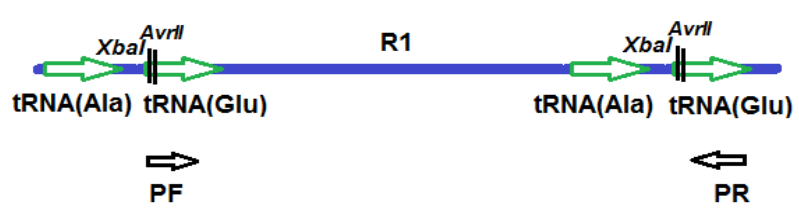

Fig. 2 Schematic structures of the hin-regions of $X$. campestris, genotype hin I corresponding to the type strain ATCC 33913T. 
distinguish close-related Xanthomonas spp. strains below species level [36]. Based on the nucleotide polymorphism and pathovar-specific deletions in intergenic region (IR) (Fig. 2), robust species and inter-specific identification had been provided for $X$. campestris pv. campestris (referent strain, the length of the IR-140 bp), X. campestris pv. raphani (2 bp deletion, type I), $X$. vesicatoria (25 bp deletion, type IIa), $X$. gardneri (27 bp deletion, type IIb), $X$. oryzae pv. oryzae (35 bp, type IIIa), X. oryzae pv. oryzicola (36 bp, type IIIb), and X. arboricola (7 bp, type IV). The cluster analysis of the DNA sequences (data not shown) had revealed six major groups, authentically. Five of them corresponded to the previously revealed species. As it was shown by $16 \mathrm{~S}$ rRNA, gyrB and whole-genome sequence analysis, $X$. axonopodis ( $9 \mathrm{bp}$ deletion, type V), X. citri (type V) and X. fuscans (V) formed the single clade based on the $100 \%$ homologous IR sequences. $X$. albilineans and $X$. transluceans did not contain Xcc0006 gene and IR. The results obtained by saAFLP correlated with the previously defined topology. We robustly revealed eight species (as for $g y r B$ ), three subgroups for $X$. campestris, according to the pathovars pv. campestris and pv. raphani; two subgroups for $X$. oryzae (pv. oryzae, pv. oryzicola); two subgroups for $X$. arboricola.

Then, we sequenced and provided cluster analysis for the hin-region that, possibly, played the role into host-plant specificity and virulence capacity [39] (Fig. 1b). The schematic structure of the hin-region is shown in Fig. 2.

At the intra-species level, hin-region (R1) sequences were unique, but at the inter-species level, the sequences identities were $30 \%-98 \%$. On average, six substitutions were found for the strains belonging to the same pathovar. Based on the hin-region structure, all strains were reliably delineated into eight distinct hin genotypes (I-VII).These groups correlated with the species and pathovar origins, in other words, reflected the practical taxonomic classification. The data exposed hin-region as a potential marker for the diagnostics of comprehensive genus Xanthomonas at the inter-species level.

\subsection{Genus Ralstonia}

After inoculation of tomato and geranium test plants and analysis of complete DNA sequences of the 16S rRNA gene (Gene Bank numbers are KJ606332-KJ606343), it had been shown that all studied strains belonged to the R. solanacearum (Rs) species complex ( $>99.98 \%$ similarity with type strain Rs K60), race 3, biovar 2 (R3B2). Through the analysis of the gyrB gene, we authentically identified all strains as Rs, phylotype IIB [22]. They were grouped together with strains isolated from temperate region all over the world [47-49]. The gyrB nucleotide sequences were $100 \%$ identical to the DNA sequences of the strain UW551, introduced long time ago to the cold regions of USA and Europe from Kenya [49]. The saAFLP analysis of the strains revealed the same pattern with UW551 and was specific for phylotype IIB. The saAFLP pattern was comprised of 32 DNA fragments. To design specific primers for PCR amplification and sequencing of the phylotype II hin-regions, we used whole-genome sequences of Ralstonia sp. (Table 1) and related bacteria Cupriavidus spp. retrieved from Gene Bank. The primers (5'-CTTCGCAGCGTAGACGGAAAC-3' (RsF79) and 5'-CTTTGCAATGCGCTTCTGATG-3' (RsR715)) were tested for the specificity on the wide-range sampling of Ralstonia spp. strains. The 566 bp PCR product (R1 located between the 1st and 2nd tRNA (Glu) genes) was revealed only for the strains of the phylotype II, R3B2. The determined hin-region sequences were compared to the corresponding sequences of the other phylotypes retrieved from Gene Bank. The amount of specific substitutions for phylotype I was three, for phylotype IIA-6, IIB-13, IV-4. The average sequence variability (15.8\%, including indels) exceeded the 16s rRNA (3.7\%) and gyrB (8.2\%) ones. These values could be 
understated partially due to inclusion of relatively small sample size. Using saAFLP and hin-region, better separation of closely related $R s$ strains was obtained compared to mutS gene $[22,50]$, indicating the potential of these two approaches for diagnostics of four phylotypes (Table 2).

Table 1 Presence of tRNA (Glu) copies and structure of hin-region in the whole sequenced genomes of the strains of genera Ralstonia and Sinorhizobium.

\begin{tabular}{|c|c|c|c|c|c|c|}
\hline Strain & $\mathrm{CTC}^{*}$ & TTC* & tRNA structure & Begin** & End** & Role \\
\hline \multirow{4}{*}{ S. fredii NGS234 } & \multirow{4}{*}{1} & \multirow{4}{*}{3} & \multirow{4}{*}{ (Glu) 4} & 1451200 & 1451275 & \multirow{4}{*}{ s } \\
\hline & & & & 1451466 & 1451540 & \\
\hline & & & & 1455542 & 1455616 & \\
\hline & & & & 1455835 & 1455909 & \\
\hline \multirow{4}{*}{ S. medicae WSM419 } & \multirow{4}{*}{1} & \multirow{4}{*}{3} & \multirow{4}{*}{ (Glu) 4} & 1531855 & 1531930 & \multirow{4}{*}{ s } \\
\hline & & & & 1532147 & 1532222 & \\
\hline & & & & 1532279 & 1532353 & \\
\hline & & & & 1532539 & 1532614 & \\
\hline \multirow{4}{*}{ S. meliloti 1021} & \multirow{4}{*}{1} & \multirow{4}{*}{3} & \multirow{4}{*}{ (Glu) 4} & 1862108 & 1862183 & \multirow{4}{*}{$\mathrm{s}$} \\
\hline & & & & 1862401 & 1862476 & \\
\hline & & & & 1862534 & 1862608 & \\
\hline & & & & 1862790 & 1862865 & \\
\hline \multirow{2}{*}{ R. eutropha JMP134 } & \multirow{2}{*}{0} & \multirow{2}{*}{2} & \multirow{2}{*}{ (Ala-Glu-Asp) 2} & 2339565 & 2339640 & \multirow{2}{*}{$\mathrm{n} / \mathrm{p}$} \\
\hline & & & & 2340159 & 2340234 & \\
\hline \multirow{2}{*}{ R. solanacearum UW551 } & \multirow{2}{*}{0} & \multirow{2}{*}{2} & \multirow{2}{*}{ (Ala-Glu-Asp) 2} & 5012672 & 5012747 & \multirow{2}{*}{$\mathrm{p} / \mathrm{p}$} \\
\hline & & & & 5013162 & 5013237 & \\
\hline \multirow{2}{*}{ R. solanacearum GMI1000 } & \multirow{2}{*}{0} & \multirow{2}{*}{2} & \multirow{2}{*}{ (Ala-Glu-Asp) 2} & 1241767 & 1241842 & \multirow{2}{*}{$\mathrm{p} / \mathrm{p}$} \\
\hline & & & & 1242236 & 1242311 & \\
\hline \multirow{2}{*}{ R. solanacearum CFBR2957 } & \multirow{2}{*}{0} & \multirow{2}{*}{2} & $(A l a-G l u-A s n) 2$ & 2236101 & 2236026 & $n / n$ \\
\hline & & & (Ala-Glu-Asp) 2 & 2236591 & 2236516 & $\mathrm{p} / \mathrm{p}$ \\
\hline D colanacoanum $\mathrm{PCLO} 7$ & & & & 2308786 & 2308711 & \\
\hline R. solanacearum PCI07 & 0 & 2 & (Ala-Glu-Asp) 2 & 2309250 & 2309175 & $\mathrm{p} / \mathrm{p}$ \\
\hline$P$ ситияіi $\mathrm{P} 24$ & 0 & 2 & (Glu) 2 & 343062 & 343137 & $n / n$ \\
\hline R. syzygll R24 & 0 & 2 & (Glu) 2 & 343526 & 343601 & $\mathrm{p} / \mathrm{p}$ \\
\hline
\end{tabular}

*Anticodon; **tRNA (Glu) positions; s—symbiont; p/p—plant pathogen; n/p—non pathogen.

Table 2 The resolutions of the methods to study the biodiversity of the genera Sinorhizobium, Ralstonia and Xanthomonas.

\begin{tabular}{lllll}
\hline Methods & Genus & Species & Phylotype/Pathovar & Strain/Sequevar \\
\hline Phenotypic methods & & & & \\
\hline Biochemical analysis & + & $+/-$ & - & $+/-$ \\
Inoculation/nodulation & + & $+/-$ & $+/-$ & - \\
\hline Genotypic methods & & & & - \\
\hline 16S rRNA & + & $+/-$ & - & - \\
16S-23S rRNA & + & + & - & - \\
gyrB & + & + & + & - \\
Xcc0006-0007* & + & + & $\mathrm{N} / \mathrm{A}$ & - \\
mutS** & + & $+/-$ & $+/-$ & - \\
nodD & $+* *$ & $+/-$ & $\mathrm{N} / \mathrm{A}$ & $+/-$ \\
egl** & + & + & + & $+/-$ \\
saAFLP & + & + & + & - \\
hin-region PCR & - & + & + & - \\
\hline
\end{tabular}

*only for genera Xanthomonas; **only for R. solanacearum; ***only for genus Sinorhizobium; N/A—not applicable. 


\subsection{Genus Sinorhizobium/Ensifer Group}

$\begin{array}{rrrr}\text { Nine nitrogen-fixing } & \text { fast-growing } & \text { strains } \\ \text { Sinorhizobium } & \text { spp., } & \text { prospective } & \text { for }\end{array}$
commercialization as a microbial seed inoculant to soybeans seeds prior to planting, were studied in this work. These strains were isolated from nodules of the different cultivars of soybeans ("Ustya", "Svetlaya", Glycine soja) in Russia in 2013. On the basis of the $16 \mathrm{~S}$ rRNA sequences, biochemical characteristics and host specificity, nine investigated strains were attributed to the genus Ensifer. Based on the $16 \mathrm{~S}$ rRNA sequence analysis, all strains were clustered together with $S$. americanum, $S$. fredii and $S$. xinjiangense, the last is considered as heterotypic synonym of $S$. fredii [51]. Thus, 16S rRNA gene sequence analysis lacked resolving power at species (or genomovars) level and below (genus variability < $0.5 \%$ ) [52]. The gyrB nucleotide sequences of the studied strains were $97 \%-100 \%$ identical to the type strain S. fredii ATCC 35423T. The "Ustya" strains (U1, U2 and U3) were $100 \%$ identical to the ATCC 35423T. The strains isolated from G. soja (Gs1, Gs2 and Gs3) formed separate branch and were closely related to the broad-host-range strains USDA257 (enter symbiosis with wild soybean cultivars and some agronomical soybean cultivars) and NGR234 (unable to enter symbiosis with any soybean). The strains from "Svetlaya" (S1, S2, S3) formed a tight cluster with HH103 (forms nodules on agronomically advanced soybean cultivars) [53]. The sequences were highly similar between all Ensifer species, and their variability for the genus saAFLP analysis, ranging from $0 \%$ to $2.1 \%$, revealed three types of saAFLP patterns correlated with host plant of studied strains. Based on the conservative regions of the tRNA (Glu) genes, the specific primers for the genus were developed. Nearly 300 bp PCR fragments (R1) were sequenced and compared to the corresponding sequences from Gene Bank. The R1 sequences were unique for the $S$. fredii group and did not reveal any homology with whole-genome sequences of other species or genera. The topology of NJ tree was similar to the data obtained before $[54,55]$. The strains U1-3 and S1-3 were robustly clustered together with the strains HH103 (97\%-99\% identity) and ATCC 35423T, which are able to nodulate soybeans. These data were supported by inoculation test, which showed the occurrence of wide-host range for these strains. Beside G. soja and G. max, they were able to effectively nodulate Phaseolis vulgaris and Vigna sp. The strains Gs1-3 formed separate clusters closely related to USDA257. The sequence variability of the hin-regions for species $S$. fredii was ranging from $0 \%$ to $10.5 \%$, which was reflected in the high separability values.

\section{Conclusions}

Summarizing all data below, we concluded that only integrated approach should be applied for identification and diagnostics of genera with intricate taxonomic structure. This can be based on the combination of phenotypic and genotypic tools. Genotypic approach should include the analysis of more than one phylogenetic marker gene, or methods with different resolution. Thus, we suggested: (1) 16S rRNS or $g y r B$ for analysis of bacteria at the genera-species level; (2) hin-region and saAFLP for determination of the inter-species variability. Furthermore, hin-region PCR may be applied singly as a rapid, efficient and low-cost method for direct monitoring and diagnostics of the species in the investigated genera.

\section{Acknowledgments}

This work was supported by the programme "support of young scientists" by Presidium Russian Academy of Science. The authors are grateful to Vasily Zotov and Sofia Khapchaeva for their technical assistance.

\section{References}

[1] De La Fuente, L., and Burdman, S. 2011. "Pathogenic 
and Beneficial Plant-Associated Bacteria." In Encyclopedia of Life Support Systems (EOLSS), edited by Lal, R. Oxford, UK: EOLSS Publishers.

[2] Beattie, G. A. 2006. "Plant-Associated Bacteria: Survey, Molecular Phylogeny, Genomics and Recent Advances." In Plant-Associated Bacteria, edited by Gnanamanickam, S. S. Netherlands: Springer, 1-7.

[3] Vandamme, P., Pot, B., Gillis, M., de Vos, P., Kersters, K., and Swings, J. 1996. "Polyphasic Taxonomy, a Consensus Approach to Bacterial Systematics." Microbiol. Rev. 60 (2): 407-38.

[4] Goulter, K., and Randles, J. 1997. "Serological and Molecular Techniques to Detect and Identify of Plant Pathogens." In Plant Pathogens and Plant Diseases, edited by Brown, J. F., and Ogle, H. J. Armidale, Australia: Rockvale Publication, 172-91.

[5] Jones, S. W., Dobson, M. E., Francesconi, S. C., Schoske, R., and Crawford, R. 2005. "DNA Assays for Detection, Identification and Individualization of Select Agent Microorganisms." Croat. Med. J. 46 (4): 522-9.

[6] Zakhia, F., and de Lajudie, P. 2006. "Modern Bacterial Taxonomy: Techniques Review-Application to Bacteria that Nodulate Leguminous Plants (BNL)." Can. J. Microbiol. 52 (3): 169-81.

[7] Albuquerque, P., Mendes, M. V., Santos, C. L., Moradas-Ferreira, P., and Tavares, F. 2009. "DNA Signature-Based Approaches for Bacterial Detection and Identification." Sci. Total Environ. 407 (12): 3641-51.

[8] Almeida, N. F., Yan, S., Cai, R., Clarke, C. R., Morris, C. E., Schaad, N. W., Schuenzel, E. L., Lacy, G. H., Sun, X., Jones, J. B., Castillo, J. A., Bull, C. T., Leman, S., Guttman, D. S., Setubal, J. C., and Vinatzer, B. A. 2010. "PAMDB, a Multilocus Sequence Typing and Analysis Database and Website for Plant-Associated Microbes." Phytopathology 100 (3): 208-15.

[9] Coenye, T., Gevers, D., Van de Peer, Y., Vandamme, P., and Swings, J. 2005. "Towards a Prokaryotic Genomic Taxonomy.” FEMS Microbiol. Rev. 29 (2): 147-67.

[10] Bochner, B. R. 2009. "Global Phenotypic Characterization of Bacteria." FEMS Microbiol. Rev. 33 (1): 191-205.

[11] Miller, S. A., Beed, F. D., and Harmon, C. L. 2009. "Plant Disease Diagnostic Capabilities and Networks." Annu. Rev. Phytopathol. 47: 15-38.

[12] Narayanasamy, P. 2011. Microbial Plant Pathogens-Detection and Disease Diagnosis: Bacterial and Phytoplasmal Pathogens. Netherlands: Springer, 2-125.

[13] Ahmad, F., Babalola, O. O., and Tak, H. I. 2012. "Potential of MALDI-TOF Mass Spectrometry as a Rapid Detection Technique in Plant Pathology: Identification of Plant-Associated Microorganisms.” Anal. Bioanal. Chem.
404 (4): 1247-55.

[14] Biswas, S., and Rolain, J. M. 2013. "Use of MALDI-TOF Mass Spectrometry for Identification of Bacteria that Are Difficult to Culture." J. Microbiol. Methods 92 (1): 14-24.

[15] Bulgarelli, D., Schlaeppi, K., Spaepen, S., Ver Loren van Themaat, E., and Schulze-Lefert, P. 2013. "Structure and Functions of the Bacterial Microbiota of Plants." Annu. Rev. Plant. Biol. 64: 807-38.

[16] Guttman, D. S., McHardy, A. C., and Schulze-Lefert, P. 2014. "Microbial Genome-Enabled Insights into Plant-Microorganism Interactions." Nature Reviews Genetics 15: 797-813.

[17] López, M. M., Llop, P., Olmos, A., Marco-Noales, E., Cambra, M., and Bertolini, E. 2009. "Are Molecular Tools Solving the Challenges Posed by Detection of Plant Pathogenic Bacteria and Viruses?" Curr. Issues Mol. Biol. 11 (1): 13-46.

[18] Hayward, A. C. 1993. "The Host of Xanthomonas." In Xanthomonas, edited by Swings, J. G., and Civerolo, E. L. London: Chapman and Hall, 52-4.

[19] Hayward, A. C. 1994. "The Hosts of Pseudomonas solanacearum." In Bacterial Wilt: The Disease and Its Causative Agent, Pseudomonas solanacearum, edited by Hayward, A. C., and Hartman, G. L. Wallingford, UK: CAB International, 9-25.

[20] Vauterin, L., Hoste, B., Kersters, K., and Swings, J., 1995. "Reclassification of Xanthomonas." Int. J. Syst. Bact. 45 (3): 472-89.

[21] Young, J. M., Park, D. C., Shearman, H. M., and Fargier, E. 2008. "A Multilocus Sequence Analysis of the Genus Xanthomonas.” Syst. Appl. Microbiol. 31 (5): 366-77.

[22] Fegan, M., and Prior, P. 2005. "Recent Developments in the Phylogeny and Classification of Ralstonia solanacearum." Acta Hortic. 695: 127-36.

[23] Fargier, E., and Manceau, C. 2007. "Pathogenicity Assays Restrict the Species Xanthomonas campestris into Three Pathovars and Reveal Nine Races within $X$. campestris pv. campestris." Plant Pathol. 56 (5): 805-18.

[24] Meyer, D. F., and Bogdanove, A. J. 2009. "Genomics-Driven Advances in Xanthomonas Biology." In Plant Pathogenic Bacteria: Genomics and Molecular Biology, edited by Jackson, R. W. Norfolk: Caister Academic Press, 147-61.

[25] Brown, D. 2009. "Ralstonia solanacearum and Bacterial Wilt in the Postgenomics Era." In Plant Pathogenic Bacteria: Genomics and Molecular Biology, edited by Jackson, R. W. Norfolk: Caister Academic Press, 175.

[26] Rodriguez, L. M., Grajales, A., Arrieta-Ortiz, M. L., Salazar, C., Restrepo, S., and Bernal, A. 2012. "Genomes-Based Phylogeny of the Genus Xanthomonas." 
BMC Microbiol. 23: 12-43.

[27] Meng, F. 2013. "Ralstonia solanacearum Species Complex and Bacterial Wilt Disease." J. Bacteriol. Parasitol. 4 (2): e119.

[28] Chen, W. X., Yan, G. H., and Li, J. L. 1988. "Numerical Taxonomic Study of Fast-Growing Soybean Rhizobia and a Proposal that Rhizobium fredii Be Assigned to Sinorhizobium Gen. Nov.” Int. J. Syst. Bacteriol. 38 (4): 392-7.

[29] Rodriguez-Navarro, D., Oliver, M., Contreras, A., and Ruiz-Sainz, J. 2011. "Soybean Interactions with Soil Microbes, Agronomical and Molecular Aspects." Agron. Sustain. Dev. 31 (1): 173-90.

[30] Bradbury, J. F. 1984. "Genus II. Xanthomonas Dowson 1939, 187AL.” In Bergey's Manual of Systematic Bacteriology, 1st ed., edited by Krieg, N. R., and Holt, J. G. Baltimore: Williams and Wilkins, 199-210.

[31] Brenner, D. J., Krieg, N. R., Garrity, G. M., Staley, J. T., Boone, D. R., De Vos, P., Goodfellow, M., Rainey, F. A., and Schleifer, K. H. 2005. Bergey's Manual of Systematic Bacteriology: Part C, The Alpha-, Beta-, Delta- and Epsilonproteobacteria. New York: Springer, 358-61.

[32] Gerhardt, P., Murray, R. G., Costilow, R. N., Nester, E. W., Wood, M. W., Krieg, N. R., and Phillips, G. B. 1981. Manual of Methods for General Bacteriology. Washington, USA: American Society for Microbiology, 34-51, 328-64, 409-43.

[33] Schaad, N. W., Jones, J. B., and Lacy, G. 2001. "Xanthomonas." In Laboratory Guide for Identification of Plant Pathogenic Bacteria, 3rd ed., edited by Schaad, N. W., Jones, J. B., and Chun, W. St. Paul, MN: APS Press, 233.

[34] Lane, D. J. 1991. "16S-23S rRNA Sequencing Nucleic Acid Techniques in Bacterial Systematics." In Nucleic Acid Techniques in Bacterial Systematics, edited by Stackebrandt, E., and Goodfellow, M. Chichester, United Kingdom: John Wiley and Sons, 115-75.

[35] Yamamoto, S., and Harayama, S. 1995. "PCR Amplification and Direct Sequencing of gyrB Genes with Universal Primers and Their Application to the Detection and Taxonomic Analysis of Pseudomonas putida Strains." Appl. Environ. Microbiol. 61 (3): 1104-9.

[36] Punina, N. V., Zotov, V. S., Kuznetsov, B. B., Ignatov, A. N. 2008. "Evaluation of Variability of 16S-23S Internal Transcribed Spacer Region, gyrB and Xcc0006-0007 genes and development of PCR diagnostics for plant pathogenic Xanthomonas." Bulletin of MSOU—Natural Sciences 2: 3-17. (in Russian)

[37] Vos, P., Hogers, R., Bleeker, M., Reijans, M., Van de Lee, T., Hornes, M., Frijters, A., Pot, J., Peleman, J., and Kuiper, M. 1995. “AFLP: A New Technique for DNA Fingerprinting." Nucleic Acids Res. 23 (21): 4407-14.
[38] Punina, N. V., Zotov, V. S., Parkhomenko, A. L., Kuznetsova, L. N., Parkhomenko, T. U., and Topunov, A. F. 2013. "Studying of Genetic Diversity of Bacillus thuringiensis from Different Geo-Ecological Areas of Ukraine by Analysis of Genes 16S rRNA, gyrB, AP-PCR and saAFLP." Acta Naturae 5 (16): 75-85.

[39] Zotov, V. S., Punina, N. V., Khapchaeva, S. A., Didovych, S. V., Melnichuk, T. N., and Topunov, A. F. 2013. "A New Taxonomic Marker of Nodule Bacteria of the Genus Rhizobium and Its Evolution." Rus. J. of Gen.: App. Res. 3 (2): 102-13.

[40] Zotov, V. S., Punina, N. V., and Topunov, A. F. 2013. The Method of Identification and Differentiation of Prokaryotes. Russian Patent 2,486,251, filed August 25, 2011 and issued June 23, 2013.

[41] Altschul, S. F., Gish, W., and Miller, W. 1990. "Basic Local Alignment Search Tool.” J. Mol. Biol. 215 (3): 403-10.

[42] Thompson, J. D., Higgins, D. G., and Gibson, T. J. 1994. "CLUSTAL W: Improving the Sensitivity of Progressive Multiple Sequence Alignment through Sequence Weighting, Position-Specific Gap Penalties and Weight Matrix Choice." Nucl. Acids Res. 22 (22): 4673-80.

[43] Nei, M., and Kumar, S. 2000. Molecular Evolution and Phylogenetics. NY: Oxford Univ. Press, 336.

[44] Rzetsky, A., and Nei, M. 1992. "Theoretical Foundation of the Minimum-Evolution Method of Phylogenetic Inference.” Mol. Biol. Evol. 10 (5): 1073-95.

[45] Kumar, S., Tamura, K., and Nei, M. 2004. "MEGA3: Integrated Software for Molecular Evolutionary Genetics Analysis and Sequence Alignment." Briefings in Bioinformatics 5 (2): 150-63.

[46] Parkinson, N., Cowie, C., Heeney, J., and Stead, D. 2009. "Phylogenetic Structure of Xanthomonas Determined by Comparison of gyrB Sequences." Int. J. Syst. Evol. Microbiol. 59 (2): 264-74.

[47] Sudarikova, S. V., and Shneyder, E. Y. 2000. "Brown Rot of Potato." Zashchita i Karantin Rastenii. 12: 28-9. (in Russian)

[48] Matveeva, E. V., Pekhtereva, E. S., Nikolaeva, E. V., and Schaad, N. W. 2003. "Pathogenicity, Virulence and Phenotypic Diversity of Ralstonia solanacearum Strains in Potato in Russian Federation." Phytopathology 93 (6): 58.

[49] Swanson, J. K., Yao, J., Kersten, J. T., and Allen, C. 2005. "Behavior of Ralstonia solanacearum Race 3 Biovar 2 during Latent and Active Infection of Geranium." Phytopathology 95 (2): 136-43.

[50] Fegan, M., Taghavi, M., Sly, L. I., and Hayward, A. C. 1998. "Phylogeny, Diversity and Molecular Diagnostics of Ralstonia solanacearum." In Bacterial Wilt Disease: Molecular and Ecological Aspects, edited by Prior, P., 
Allen, C., and Elphinstone, J. Berlin, Germany: Springer, 19-33.

[51] Miet Martens, M., Dawyndt, P., Coopman, R., Gillis, M., De Vos, P., and Willems, A. 2008. "Advantages of Multilocus Sequence Analysis for Taxonomic Studies: A Case Study Using 10 Housekeeping Genes in the Genus Ensifer (Including Former Sinorhizobium).” Int. J. Syst. Bacteriol. 51 (1): 200-14.

[52] Tan, Z. Y., Xu, X. D., Wang, E. T., Gag, J. L., Martínez-Romero, E., and Chen, W. X. 1997. "Phylogenetic and Genetic Relationships of Mesorhizobium tianshanense and Related Rhizobia." Int. J. Syst. Bacteriol. 47 (3): 874-9.

[53] Margaret, I., Becker, A., Blom, J., Bonilla, I., Goesmann, A., Göttfert, M., Lloret, J., Mittard-Runte, V., Rückert, C., Ruiz-Sainz, J. E., Vinardell, J. M., and Weidner, S. 2011.
"Symbiotic Properties and First Analyses of the Genomic Sequence of the Fast-Growing Model Strain Sinorhizobium fredii HH103 Nodulating Soybean." J. Biotechnol. 155 (1): 11-9.

[54] Saldana, G., Martinez-Alcantara, V., Vinardell, J. M., Bellogin, R., Ruiiz-Sainz, J., and Balatti, P. A. 2003. "Genetic Diversity of Fast-Growing Rhizobia that Nodulate Soybean (Glycine max L. Merr.)." Arch. Microbiol. 180 (1): 45-52.

[55] Tian, C. F., Zhou, Y. J., Zhang, Y. M., Li, Q. Q., Zhang, Y. Z., Li, D. F., Wang, S., Wang, J., Gilbert, L. B., Li, Y. R., and Chen, W. X. 2012. "Comparative Genomics of Rhizobia Nodulating Soybean Suggests Extensive Recruitment of Lineage-Specific Genes in Adaptations." Proc. Natl. Acad. Sci. 109 (22): 8629-34. 